\title{
PRESIDENTIAL ELECTION DISPUTES \\ IN UGANDA \\ A Critical Analysis of the Supreme Court Decisions
}

\begin{abstract}
Fred Sekindi
Dr. Fred Sekindi is a lecturer in International Public Law and International Human Rights at Nkumba University and a consultant tutor with the African Prisons Project in Uganda email: fredsekindi@gmail.com
\end{abstract}

\begin{abstract}
This article analyses the constitutional and domestic legal framework under which the president of Uganda has been elected since 1995. The focus is on the three Supreme Court decisions in the adjudication of presidential electoral disputes in 2001, 2006 and in 2016. It argues that presidential electoral laws are deficient in their capacity to facilitate fair political contestation. This is because they were not adequately constructed to address electoral malpractices pertaining to Uganda, and they have been interpreted to favour the incumbent.
\end{abstract}

Keywords: Constitution of Republic of Uganda 1995, electoral offences, presidential elections, presidential electoral laws, presidential electoral petition, Supreme Court

\section{INTRODUCTION}

The post-1995 constitutional reforms in Uganda were aimed at averting violent struggles for political power. One of these reforms was the introduction of direct presidential elections. The significance of this is that since the Constitution of 1995 came into force, and for the first time in the country's history, the majority of Ugandans could elect their president directly. In addition, more Ugandans than before are eligible to stand for election as president. This article studies how the Supreme Court in Uganda has adjudicated presidential electoral disputes since 1995. It evaluates the efficacy of the constitutional and domestic legal framework under which the president of Uganda is elected, in protecting fair 
political contestation in order to achieve its objectives. This article further argues that presidential electoral laws have been constructed without attention to the electoral lawlessness prevalent in Uganda. These laws make it almost impossible to challenge the outcome of the election, particularly where the declared winner is the incumbent. Therefore, the laws are incapable of converting votes into a truly democratic choice, and are consequently unable to avert violent struggles for political power.

The article opens with a background to the development of the post-1995 legal framework under which the president of Uganda is elected. This is followed by an analysis of the decisions of the Constitutional Court in the presidential election petitions of 2001, 2006 and 2016. This in turn is followed by an explanation of the principles employed by the Constitutional Court in adjudicating presidential electoral complaints and a discussion of the deficiencies in the presidential electoral laws. The article also offers an alternative interpretation to the principles for adjudicating presidential electoral laws in an effort to address the electoral lawlessness that has plagued presidential elections in Uganda since 1996. Finally, the findings of this study are discussed in the conclusion. Methodologically, this article is a product of desk research including a review of primary sources (cases, constitutions, and statutes) and secondary documents (books, journals, and newspapers).

\section{BACKGROUND}

Britain organised the first general elections in Uganda in 1962 in order to prepare the country for self-rule. The elections were contested by the Democratic Party (DP), Kabaka Yeka (KY) and the Uganda People's Congress (UPC). Although the DP received a majority in the National Assembly, the KY and UPC merged to become the KY-UPC and became a majority. They formed the government under President Edward Mutesa II, the leader of KY, while Milton Obote of the UPC became the Prime Minister (Kasozi 1994, p. 58). The transfer of power from the Colonial Governor, Sir Walter Coutts, to President Mutesa II after the 1962 general elections is the only non-violent and undisputed transfer of government in the country's history. Mutesa II was removed from power by Obote in a military coup in 1966. Five years later Obote was disposed by Amin Dada in the same manner. The Uganda National Liberation Front (UNLF) toppled Amin's regime in 1979 and installed Yusufu Lule as president. After two months Lule was removed from power by the UNLF and replaced by Godfrey Binaisa. The military commission ousted Binaisa and organised the first post-independence general elections in 1980, which have been widely discredited as fraudulent (Mudola 1988, pp. 280298; Museveni 1997, p. 21). 
The 1980 elections were contested by the Conservative Party (CP), DP, Uganda Patriotic Movement (UPM) and UPC. It was a common occurrence during election campaigns for the armed forces to harass, torture and kill UPC's political opponents, and also to disperse political rallies organised by its political opponents (Mukasa 1980; Tamale 1980). By this time, Obote had distorted the ethnic composition of the armed forces in favour of members of his own tribe, the Langis (Mukasa 1980). Events before, during and after the elections suggest that the elections were neither free nor fair. Also, during the elections the chairman of the military commission, Paulo Muwanga, usurped the powers of the electoral commission by decree, Legal Notice No. 10 1980, which authorised him to assume responsibility for announcing the results. Mudola claims that this decree was issued for Muwanga to reverse the DP's victory once it became apparent that they were on the verge of winning the majority of seats in the National Assembly (Mudola 1980, p. 291). This same decree (1980, para. 4.6) also removed from the courts the authority to adjudicate any disputes arising out of the elections. These are some of the reasons why the credibility of the 1980 elections has been widely contested. The UPC under Obote took power while the DP, which had garnered the most votes but lacked military might, formed the opposition. Yoweri Museveni, then the UPM party leader, declared that the elections were fraudulent and unacceptable. Museveni formed a political organisation, the National Resistance Movement (NRM), which contested the validity of the elections through a popular and bloody armed conflict. Obote was removed from power in 1985 by Tito Okello Lutwa in an armed coup. In 1986, Museveni's NRM seized power from Lutwa following a bloody civil war. Thus, since independence, Uganda has had eight heads of state, seven of whom came to power by overthrowing the previous government.

After Museveni's NRM seized power, it embarked on the process of adopting a new constitution that would usher in a new democratic dispensation. The Constitution Commission (CC) was established for the purpose of consulting Ugandans on this new constitution and for writing a draft constitution. The Constitution Commission's Report (CCR 1992, p. 385) notes that 'there was an overwhelming desire among Ugandans to develop a new constitution containing fair and transparent electoral laws that would allow for the smooth transfer of political power'. In addition it noted that (1992, p. 87):

The people are demanding an end to sudden and violent changes of government and the consequent political, social and economic destabilisation that has caused so much suffering. They castigate the "fashion" "of going to the bush" to resolve political and constitutional conflicts which has resulted in terrible consequences to the ordinary 
people who get caught up in the conflicts. They demand an effective mechanism to be put in place to ensure orderly transfer of power so that the people's lives are not unduly disturbed.

According to the CCR (1992, p. 94), 'the major problem in Uganda had been that those in power were reluctant to subject themselves to the electoral process'. The report therefore endorsed the demands of the people for leaders at all levels to be elected at known and regular intervals; and for the electoral process to be designed and implemented to minimise abuse. The purpose of this second clause is to guard against electoral results being challenged by violent means on the basis that they had been rigged (1992, p. 95).

The election of the presidency was not subject to direct elections under the previous constitutions, namely, the Uganda (Independence) Order in Council 1962 and the Constitution of Republic Uganda 1967. In this regard the CCR (1992, p. 134) notes 'that there was overwhelming support for the concept of a democratically elected president, which emanated from the people's experience of both colonial and independent Uganda'. It also observed that: 'the people want direct participation in the elections of their leader and also prefer to have a president who commands a national following and not one whose support is based on a particular region, group, or force'(1992, p. 134). The CCR (1992, p. 320) further reported that: 'There has been concern about the lack of orderly succession of government. Where leaders did not appear to be prepared to hand over power free and fair elections have been violently resisted. The culture of clinging on to political office was criticized in the many of the submissions we received'.

Thus the draft constitution of 1992, articles 105-108, provides that:

- The president should be directly elected by universal suffrage.

- The age of a president should be no less than forty years but not more than seventy-five (art.107).

- The president should have acquired at least a secondary education qualification (art.106).

- A president should be a citizen of Uganda by birth and should have been resident in Uganda for at least twelve months prior to the elections (art.107 (b)).

- In order to qualify as a presidential candidate, a candidate should have the support of a minimum of one thousand qualified voters from two-thirds of all the districts (art.108 (a)).

- A candidate in a presidential election who wins the majority of the votes cast should be declared the winner (art.108 (b)). 
- Where no candidate obtains the absolute majority, a second runoff election should be held thirty days after the previous election (art.108(c)).

- Candidates for the second run-off elections should be those who obtained the two highest results in the previous election (art.108 (d)).

- The electoral commission should declare the winner of the presidential elections within twenty-four hours of ascertaining the results (art.109).

- Any person who challenges the validity of presidential elections should be required to show that they have the support of at least five hundred thousand voters (art.110).

In October 1995 the Constitution of the Republic of Uganda was promulgated (henceforth referred to as the Constitution). Rules for managing political competition and for transferring political power were instituted then in an effort to ensure that future leaders would be elected through the popular will of Ugandans, in order to avert the old violent struggles for political power.

\section{THE 2005 AMENDMENT TO THE CONSTITUTIONAL ORDER FOR ELECTING A PRESIDENT}

On 30 September 2005, Parliament repealed art.105 (2) of the Constitution. This provision had allowed a serving president a maximum of two five-year terms. The amendment was significant in that it created unlimited terms for the office of the president, and in doing so it paved the way for the incumbent, Museveni, to run for additional terms in office. In order to enact the amendment, Parliament passed the Constitutional Amendment Act (CCA) 2005 and the Constitutional Amendment Act No.2 (CAA No.2) 2005. There were several petitions presented to Parliament as well as submissions by civil society organisations opposing the removal of limits to presidential terms (Asiimwe \& Muhozi, 2005, p. 8). Members of the ruling government in the legislature and executive branches dominated the group that favoured repealing the term limits, while opposition groups in Parliament and civil society were in the opposite camp (2005, p. 9). Both sides of the political divide traded opinions about the legality of the amendment (2005, p. 10). Surprisingly, questions about the legality of the amendment were not put before the Constitutional Court which is vested with the authority to interpret the constitution (Constitution, art.137 (1)). President Museveni's comments accentuate his argument for repealing the term limits; he is quoted as saying, 'Why should I sentence Uganda to suicide by handing over to the people we fought and defeated? It is dangerous, despite the fact that the constitution allows them to run against me' (Ngozi 2003, p. 12). Also, at his party's national conference one year after he 
started his second and last term in office, the President called for the removal of term limits from the Constitution (USAID 2005, para.1.3.4).

In 2003, Museveni's government appointed the Constitution Review Commission (CRC) to review the fundamental features of the Constitution. The Constitution Review Commission's Report (CRCR 2003, para.33.5) notes that it received over one hundred proposals for amending the Constitution from the National Executive Committee (NEC), the decision-making body of the NRM. The NEC argued that the amendments were necessary to allow for the smooth running of government because the president had routinely encountered difficulties, contradictions and inadequacies in implementing the Constitution (Ngozi 2003, p. 23). The term limits were considered a restriction on democratic choice; therefore their removal would allow Ugandans to exercise their democratic choice in electing the same person as many times as they chose (Kiwanuka 2003, p. 3).

The CRCR (2003, para.7.9.5) recommended that the question of repealing the presidential term limits should be decided by a referendum. It noted that $59 \%$ of the respondents were against lifting the term limits (2003, para.7.9.6). Two of the commissioners, including the CRC's chair, wrote a minority report opposing the repeal of the maximum presidential tenure of two terms (2003, pp. 262-266). The media reported that the government obtained an injunction preventing newspapers from publishing an article detailing opposition to this repeal among members of the CRC (Afedura \& Atuhaire 2003).

In July 2005 a referendum was held on the government's proposals for amending the Constitution. It was boycotted by opposition parties because the contentious issue of repealing the presidential term limits was not included (2005, p. 13). It should be noted that the provision on the term limits can only be amended by a bill that obtains the support of two-thirds of all members of Parliament (Constitution art.262). Therefore, the NRM government opted to leave the issue for Parliament to determine. Most of the proposed changes to the Constitution, including repealing the term limits on the tenure of the president, were passed by Parliament after the third reading of the bill on 18 August 2005 (Asiimwe \& Muhozi 2005, p. 28).

When recommending that a person elected as president should not hold office for more than two terms of five years each, the CC (1992, p. 332) noted that:

We have also reflected the view almost unanimously advocated for by the people that the tenure of office of the President should be constitutionally limited to put an end to the phenomenon of self-styled life presidents. We have recommended a limit of two-terms of five years each for any President. 
Eleven years after the CCR, the CRC observed that the majority of respondents wished for the preservation of the two-term limits on the president. It found that changes in circumstances had not brought a divergence of opinion among Ugandans on the matter (CRCR 2003, para.7.94). It opined that in order to examine the issue of the removal of the term limits objectively, it could not merely recommend their retention or lifting. Therefore, it proposed that the matter should be subjected to an exhaustive and comprehensive debate that would provide for a nationally acceptable solution (2003, para.7.94). The proposal was ignored by the government. In order to usher in a new democratic dispensation and to garner popular support the NRM government would have to put the issue of removing the term limit to the people to determine, as was recommended by the CRC.

In addition to the amendment lacking popular legitimacy, it was also plagued by allegations of bribery. Several members of Parliament admitted that they had received financial inducements to vote in favour of the amendment, as the NRM government did not have the parliamentary majority required to pass the bill (Posner \& Young 2007, p. 3).

\section{ELECTORAL LAWS, OBLIGATIONS, AND POLITICAL COMMITMENTS IN THE CONDUCT OF ELECTIONS}

Domestic laws have been appended to the Constitution for the purpose of administering presidential elections. These are further supplemented by Uganda's willingness to be bound by regional and international treaties and political commitments, both of which are aimed at promoting free and fair elections. At the time of writing the legal framework for conducting presidential elections is provided under the Electoral Commission Act (ECA) as amended 2010; the Political Parties and Organisations Act (PPOA) as amended 2010 and the Presidential Elections Act (PEA) as amended 2010.

Since 1986 Uganda has ratified, signed or acceded to 15 international and regional treaties, 12 non-treaty standards and 9 political commitments which provide for the legal protection and promotion of democratic electoral processes (EU 2012, pp. 53-55). It is from these documents that guidelines for conducting free and fair elections and for developing democratic institutions emerge. These guidelines impose extra legal obligations and commitments for democratic elections to supplement the constitutional and domestic legal framework for conducting presidential elections in Uganda. Examples of these include the Universal Declaration of Human Rights (UDHR) 1948, International Covenant on Civil and Political Rights (ICCPR) 1966 and the African Charter on Democracy, Elections and Governance (ACDEG) 2007. 


\section{UGANDA'S CONSTITUTIONAL AND LEGAL FRAMEWORK FOR PRESIDENTIAL ELECTIONS}

The main constitutional and statutory provisions governing the election of the president of Uganda are as follows:

The 1995 Constitution art.103(1) stipulates that the election of a president shall be by universal adult suffrage through a secret ballot. It also provides that in order to be elected president, a candidate requires more than fifty percent of the total valid votes cast in the presidential election (art.103(4)). Where no candidate obtains sufficient votes as specified, a second election must be held within 40 days and the two candidates who obtain the highest number of votes shall be the only candidates (art.103 (5)). Following the amendment to repeal the two-term limits on the re-election of a president, a president may be elected for more than two terms (art.105 (2)): In order to qualify for election as president candidates must be a citizen of Uganda of not less than 35 years of age, but not more than 75 , and qualified to be a member of Parliament (art.61). To be eligible for the membership of Parliament, candidates must be a citizen of Uganda, a registered voter and have completed a minimum formal education of Advance Level Standard or equivalent (art.80 (1)).

The electoral commission is entrusted with the responsibility of managing presidential, parliamentary and local government elections (art. 61). Members of the electoral commission are appointed by the president with the approval of Parliament (art.60(1)) Thus, Parliament may reject a presidential appointee to the commission. Elections must be held within the first third of the last ninety days before the presidential term expires (art.61(2)).

The electoral commission may declare that a presidential candidate has been elected unopposed, if only one candidate is nominated after the close of nomination (art.103(6)(a)). Presidential candidates must submit to the electoral commission a document confirming that their nomination has been supported by one hundred voters in each of at least two-thirds of all the districts in Uganda (art.103(2). The Constitution, art.103(2) empowers Parliament to prescribe a procedure for the elections and assumption of office of the president, while art.104 sets out the procedure under which presidential elections may be challenged. An aggrieved presidential candidate may petition the Supreme Court for an order that a candidate declared by the electoral commission was not validly elected (art.104(1)). Under art.104(9) of the Constitution, Parliament is authorised to pass laws for challenging the conduct of presidential elections, including grounds for annulment and the rules of procedure. To give effect to arts.103(2) and 104(9), Parliament enacted the PEA and the ECA. The PEA s.59 provides grounds for challenging presidential elections.

Under the PEA s.59(5), the Supreme Court may dismiss a petition challenging presidential elections, declare which candidate was validly elected, or annul an 
election. s.59(6) of the same act provides that the Supreme Court may issue a declaration annulling elections on three grounds:

- under s.59(6)(a), where it is satisfied that there has been noncompliance with the provisions contained in the same act and the noncompliance affected the outcome of the election in a substantial manner;

- under s.59(6)(b), where it is satisfied that the candidate was not qualified for the position of the president or was disqualified;

- or under s.59(6)(c), where it is satisfied that an offence was committed under the act by the candidate in person or by the candidate's agents with the knowledge or approval of the candidate. The said offences are listed under parts IX and X of the PEA. These include bribing, obstructing and intimidating voters, and publication of false statement as to illness, death or the withdrawal of another candidate.

Under the PEA s.59 (8), the Supreme Court has the discretion to order a recount of the votes cast when hearing a petition challenging presidential elections. This is only if the Court deems it necessary and practical. The chief justice in consultation with the attorney general is statutorily authorised to make rules for the conduct of petitions seeking to annul presidential elections (PEA 2010, s.59(11)). The rules are contained in the Presidential Elections Petitions Rules 2001, SI No.13 2000.

\section{PRESIDENTIAL ELECTIONS}

Uganda's first attempt at transferring power through elections occurred in 1962, ushering in self-rule after nearly 60 years of colonialism as part of the British Empire. This was followed by highly disputed elections in 1980. In 1994, constituent assembly elections were held for the purposes of adopting the Constitution (UEC 2007, p. 2).

Upon its adoption, the Constitution introduced a one-party, so-called 'Movement System' under which political parties were allowed to exist but not to engage in political activities (Constitution art.71). Article 74 of the Constitution also provided for a referendum on the choice of a political system to be decided after five years. Therefore, five years after the Constitution was promulgated, Ugandans would decide if they wanted to maintain the 'Movement System'. The NRM interim government under the leadership of Museveni held power from 1986 and surrendered to elections in 1996, the year after the Constitution was adopted. The first presidential and parliamentary elections took place under the Movement System and Museveni was elected president for the first time. In 2000, the first referendum was held and the Movement System was retained. 
After the confirmation of the Movement System, Museveni was again elected as president in 2001. In the same year, Museveni's government appointed the CRC. In its report, the CRC recommended the return of the multi-party political system, which meant the abolition of the one-party Movement System (CRCR 2003, para.7.93). A second referendum in 2005 brought about the end of the one-party system when Ugandans overwhelmingly voted for multi-party politics (UEC 2007, p. 4). The government then passed the CAA and CAA No.2 for the purposes of effecting amendments to repeal both the one-party Movement System and the two-term limits on the re-election of a president, among other provisions of the Constitution. In the following years, opposition parties developed. President Museveni was elected again in 2006, 2011 and most recently in 2016. At the time of writing, President Museveni has been in power for 30 years. This is longer than all Uganda's post-independence leaders put together.

\section{PRESIDENTIAL ELECTORAL PETITIONS (1995-2016)}

Following the 2001, 2006 and 2016 presidential elections, two presidential candidates have been unsuccessful in their attempts to persuade the Supreme Court that the president had not been lawfully elected.

Mr. Kiiza Besigye, leader of the main opposition party, the Forum for Democratic Change (FDC), was a presidential candidate in the three elections. He petitioned the Supreme Court to nullify the elections on the grounds that Museveni had not been duly elected in the 2001 and 2006 presidential elections. In 2001 Museveni was declared by the electoral commission to be the winner of the elections with $69 \%$ of the total valid votes cast (UEC 2001, p. 3). In 2006, the incumbent gained $59 \%$ of the total valid votes cast (UEC 2006, p. 2). Besigye was runner-up in both elections with 37\% of the valid votes cast in 2001 (UEC 2001, p. 3), and 27\% in 2006 (UEC 2006, p. 2). The two electoral petitions sought to annul the outcome of the elections on almost identical grounds.

In the case of Col. Dr. Besigye Kiiza v Museveni Yoweri Kaguta and the Electoral Commission [2001] Presidential Electoral Petition No. 1 UGSC 3 (PEP No.1 2001), the petitioner made many complaints against the two respondents and their agents. These were for acts and omissions which he contended amounted to non-compliance with provisions of the PEA and the ECA, and illegal practices and offences under the same acts. The main complaints against the second respondent (the Electoral Commission) were that it allowed multiple voting and vote stuffing in many electoral districts in favour of Museveni, contrary to PEA s.32(1). It disenfranchised the petitioner's voters by deleting their names from the voter's register, contrary to PEA s.19(3) and s.50. Contrary to PEA s.120(e) and 12(f), it increased the numbers of polling stations on the eve of polling day 
without sufficient notice to candidates other than Museveni. It chased away the petitioner's polling agents or failed to ensure that they were not chased away from polling stations and tallying centers. This amounted to an attempt at interfering with the free exercise of the franchise, contrary to PEA s.26(c). It allowed or failed to prevent agents of the first respondent from interfering with electioneering activities of the petitioner and his agents, contrary to PEA s.12(e).

In his complaint against the first respondent, Museveni, the petitioner alleged that the president personally or by his agents, with his knowledge or approval, committed illegal practices and offences. These included publications of a false statement that the petitioner was suffering from AIDS. This was tantamount to using words or making statements that were malicious, contrary to PEA s.24 (5) (b). Additional allegations included offering gifts to voters, contrary to ECA s.64; and appointing partisan sections of the army to take charge of security during the elections, contrary to PEA s.43(2)(a). The Supreme Court found unanimously that there were widespread violations of the PEA and the ECA as a result of intimidation, voter buying and mismanagement of voters' registers, publication of false statements and irregular voting (PEP No.1 2001, para. 99). It also held that the second respondent did not comply with provisions of s.28 and s.32(5) of the PEA (2001, para. 88).The Court also found that in many areas of the country the principle of free and fair election was compromised (2001, para. 129). It uncovered evidence that there was cheating in a significant number of polling stations (2001, para. 101). However, by a majority of 3-2, the Court concluded that the irregularities did not 'substantially affect the outcome of the election' (2001, para. 156). Therefore, it could not annul the election under the PEA s.59(6)(a). Also, by a majority of 3-2, the Court held that no illegal practice or offence under the PEA was proved to have been committed in connection with the said election by the president personally, or with his knowledge or by his agent with his approval (2001, para. 149). Thus, it could not invalidate the elections under the PEA s.59(6)(c).

Following the outcome of the 2006 presidential elections, Besigye complained to the Constitutional Court about electoral malpractices that occurred before and during the election. In the case of Rtd. Col.Kizza Besigye $v$ the Electoral Commission and Yoweri Kaguta Museveni [2006] Presidential Electoral Petition No.1 UGSC 2 (PEP No.1 2006), the petitioner criticisms were that the elections were characterised by acts of intimidation; voter buying; lack of transparency; unfairness, and violence; and the commission of numerous offences and illegal practices by the incumbent. He alleged that Museveni personally bribed members of the electorate, and similar acts were carried out by his agents with his knowledge or approval before and during the elections. This interfered with the free exercise of the franchise, contrary to PEA s.64. 
The petitioner also complained about electoral malpractices allowed by the Electoral Commission. These include multiple voting, vote stuffing, and the failure to declare results in accordance with the law. The absence of freedom and fairness in the entire electoral process amounted to an attempt to interfere with the free exercise of the vote, contrary to PEA s.26(c). Besigye therefore contended that because of electoral illegalities which occurred before, during and after the elections, Museveni had not been duly elected as president. He petitioned for an order to annul the election.

The Court found unanimously that there was a lack of compliance with the provisions of the Constitution, PEA and the ECA in the conduct of the election (PEP No.1 2006, para. 98). It held that the Electoral Commission disenfranchised voters by removing their names from the voters' register, thus denying them the right to vote (2006, para.61). The Court also declared that the principle of free and fair elections was compromised by widespread bribery, intimidation and violence in some areas of the country. The principles of equal suffrage, transparency and secrecy were infringed by multiple voting, vote stuffing, and incorrect methods of ascertaining the results (2006, para.122). By a majority decision of 5-2, the Court found that no illegal practice or offence had been proved to its satisfaction to have been committed either by Museveni personally or by his agents with his knowledge or approval (2006, para. 128). Consequently, it declared that it could not annul the election on the alleged violation of PEA s.59(6)(c) (2006, para. 129). By a 4-3 majority, the Court ruled that the noncompliance with electoral laws did not 'substantially affect the outcome of the election' (2006, para.144).

In a dissenting opinion, Justice Kanyeihamba, (2006, paras 1-24) found that there was sufficient evidence presented for the Court to decide as follows: that the presidential election was so badly conducted, and fatally affected by irregularities, malpractices and illegalities, as to affect the final results in a substantive manner; therefore the result of the election ought not to have been upheld. He decried the fact that 'the Court, having unanimously found that the alleged contraventions of the electoral laws occurred, they were bound to annul the election, and to find otherwise would be based purely on the conjecture and personal inclination of the judges' (2006, para.19). He went further, saying (2006, para. 20):

Such an opinion would be grossly unfair to Ugandans because the $1^{\text {st }}$ respondent refused adamantly to produce the only evidence which could have helped the petitioner, $2^{\text {nd }}$ respondent, and this Court, to prove and be satisfied that the allegations that were irregularities, malpractices and illegalities were justified or unjustified. 
In other words, according to Justice Kanyeihamba, where the Court found unacceptably widespread contraventions of electoral laws that affected the quality of the election, it should have annulled the election.

In the case of Amama Mbabazi v Museveni \& Ors. (2016) Presidential Electoral Petition No.1 UGSC3 (PEP No.1 2016), the petitioner alleged that the 2016 presidential election was conducted without complying with the provisions and principles of the PEA, ECA and the Constitution. For this, he faulted the second respondent, the Uganda Electoral Commission. He sought a decision that President Museveni had not been validly elected, and an order that the election be annulled.

President Museveni was declared the winner by 5617503 votes, representing $61 \%$ of the valid votes cast; Amama Mbabazi polled 132574 votes representing $1.5 \%$ of the valid votes cast. The other candidates received votes as follows: Abed Bwanika 86075 (1\%), Baryamureeba Venansius 51086 (0.5\%), Benon Biraaro 24 675 (0.3\%), Kiiza Besigye 3270290 (35\%), Mabiriizi Joseph 23762 (0.3\%), Maureen Faith Kyalya Waluube 40598 (0.4\%) (UEC 2016, pp. 2-3).

Specific charges against the first respondent, President Museveni, were as follows:

- That he had committed several illegal practices and electoral offences personally, or through his agents with his knowledge or approval.

- It was further alleged that the second respondent, the Electoral Commission, nominated the first respondent when he had not yet been sponsored by the NRM on whose ticket he supposedly stood, contrary to PEA s.8 and s.10.

- The second respondent failed to declare the first respondent's nomination papers null and void. Instead it acted improperly when it extended the deadline to give him more time after all other candidates had submitted their respective documents, contrary to PEA s.11.

- The petitioner also claimed that his agents and supporters were abducted, and some were arrested by elements of the security forces with the knowledge of President Museveni. This was to pressurise them to vote for the President, or to refrain from voting, contrary to PEA s.76 (b).

- He further complained that his polling agents were denied information concerning the counting and tallying process, contrary to PEA s.76 (b).

- The second respondent was said to have failed to ensure that the conduct of the presidential electoral process was free and fair. As a result the petitioner's campaigns were interfered with by elements 
of the military, including the Special Forces and the so-called crime preventers under General Kale Kayihura, contrary to the PEA s.76 (c).

Counsel for the petitioner pleaded that the Court should depart from its decisions in PEPs No. 012001 and No. 01 2006. These held, inter alia, that numbers are important in assessing the effect of noncompliance with the law on the election result. In the opinion of the counsel for the petitioner, the Court had placed undue reliance on a quantitative test in interpreting the phrase 'affected the result of the election in a substantial manner', and set an extremely restrictive and nearly impossible standard for a petitioner to meet (PEP No.1 2016, para.17).

The Court found that in applying PEA s.59(6)(a) to this matter, it was respecting the spirit of the law in the Constitution art.1(4). This deals with the sovereignty of the people and provides that the people shall be governed through their will and consent' (2016, para.19). It therefore opined that s.59(6)(a) enables the Court to reflect on whether the proved irregularities affected the election to the extent that the ensuing results did not reflect the choice of the majority of voters as envisaged in art.1 (4) of the Constitution, and in fact negated the voter's intent (2016, para.20).

The Court declared that although the mathematical impact of noncompliance is critical in determining whether or not to annul an election, its evaluation of evidence and resulting decision is not exclusively based on the quantitative test. Nevertheless, it was satisfied that noncompliance did not affect the result of the election in any substantial manner (2016 para. 24). Also, the Court did not find any evidence to support the allegations that electoral violations were committed by President Museveni or by his agent with his knowledge or approval. However, it acknowledged that there were widespread violations of electoral law by the incumbent's supporters (2016, paras. 28-33). It also criticised the Uganda Electoral Commission's gross incompetence and noncompliance with electoral laws (2016, paras. 33-36).

In a unanimous ruling, the Supreme Court found that President Museveni was lawfully elected (2016, para. 38). However, it observed that the incumbent's use of his position was to the disadvantage of other candidates (2016, para. 37). It also expressed concern about the use of state resources and the unequal use of state-owned media by the president (2016, para. 37). The Court noted that it had made some important observations and recommendations with regard to the need for the reform of presidential electoral laws in its decisions in PEPs No. 01 2001 and No. 01 2006; however, many of these calls remained unanswered by the executive and the legislature (2016, para. 39-40).

In their report on the 2016 presidential and parliamentary elections, the European Union (2016) was particularly critical of the Uganda Electoral 
Commission. It noted that the Commission permitted the incumbent to use state resources for campaigns, including denying equal access to opposition parties and candidates to state media (2016, pp. 2-5). All these acts are in violation of electoral laws.

This study will now analyse the legal principles for adjudicating presidential elections in Uganda for the purposes of offering alternative interpretations, and to highlight the deficiencies in the law. The overall aim is to assess the efficacy of presidential electoral laws in facilitating fair contest for political power in order to avert violent struggles, and to promote democracy.

\section{LEGAL PRINCIPLES FOR ANNULLING ELECTIONS}

The legislative intent of s.59(6)(c) appears to be the need to prevent presidential candidates from committing electoral offences similar to those witnessed during the 1980 general elections. As discussed above, during the 1980 elections presidential candidate Milton Obote and his supporters intimidated voters and threatened their political opponents with death (Mukasa 1980, p. 2). This lawlessness disenfranchised the voters and also disadvantaged Obote's challengers in the elections. Despite this, Obote was declared president and his UPC the winner of the elections. Under the current presidential electoral legal framework, similar acts are recognised as electoral offences and they are prohibited by the PEA and the ECA.

Though the Supreme Court found violations of electoral laws (PEPs No.1 2001, No.1 2006 and No.1 2016), it held that they were not committed by President Museveni, or with his knowledge or approval by his agent. Therefore it could not invalidate the elections on the basis of s.59(6)(c). This suggests that the provision imposes an obligation on presidential candidates to conduct themselves in a manner that does not defeat or violate electoral laws. Sub section (c) also implies personal liability. Violations of electoral laws, even those from which a presidential candidate gains unfair electoral advantages, do not engage the candidate's liability if they are not committed by the candidate or by their agent with the candidate's knowledge or approval. Therefore, under s.59(6)(c), the Supreme Court may only invalidate elections where a presidential candidate fails to conform to standards of electoral conduct, or where the candidate's agent with the candidate's consent or approval, violates electoral laws.

With regard to s.59(6)(b), this provision is designed to remedy the exclusion of persons who do not meet the constitutional criteria for the presidency It is intended to preserve the calibre of presidential candidates from which the electorate can choose. 
The most contentious item under s.59(6)(a) has its origin in international human rights law. At the international level, the Universal Declaration of Human Rights (UDHR) 1948, art.21(3) provides that: 'That the will of the people shall be the basis of the authority of government. This will be expressed in periodic and genuine elections which shall be by universal and equal suffrage and shall be held by secret vote or by equivalent free voting procedures.' The International Covenant on Civil and Political Rights (ICCPR) 1966, art.25 states that:

Every citizen shall have the right and the opportunity, without any of the distinctions mentioned in art.2 and without unreasonable restrictions: (b) to vote and to be elected at genuine periodic elections which shall be by universal and equal suffrage and shall be held by secret ballot, guaranteeing the free expression of the will of the electors.

These two foundational international treaties provide the legal principle that the authority to govern shall be based on the will of the people as expressed in periodic and genuine elections. The concept of a popular government that emerges out of genuine elections is also common to regional treaties. In Africa, it is found in the African Charter on Human and Peoples' Rights (ACHPR) 1981, art. 13(1). In the Americas, it is provided for by the American Convention on Human Rights (ACHR) 1969, art.23; and in Europe it is found under the First Protocol to the European Convention on Human Rights (ECHR) 1950, art.3. Together, international and regional treaties provide the source of principles that capture the human aspiration to be governed through the genuine will of the people and underpin it as a legal obligation that states must observe. The legal obligation to govern, based on the genuine will of the people, has been included in the constitutions of many states. African examples of these include the Constitution of Republic of Angola 2010, art.4(1); the Constitution of the Republic of Benin 1990, arts. 3-6; and in Uganda, The Constitution art.1(4).

The legal requirement to govern through consent has international, regional and domestic appeal. International, regional and domestic rules cumulate in universal legal principles which provide a basis for measuring whether a state's actions give effect to the human aspiration for rule by consent. These legal instruments provide standards for conducting elections with integrity, protecting the political environment and citizen participation.

These principles act as a basis for measuring whether domestic electoral laws violate the accepted standards. For example, in the case of Luis Felipe Bravo Mena v Mexico (10/07/1993), the Inter-American Commission on Human Rights (IACHR) held that international standards are applicable in any case in which the rights of individuals, political or otherwise, are infringed. The case related to various 
allegations of electoral irregularities which the government of Mexico argued were solely within the purview of domestic remedial organs. Similarly, in Zdanoka $v$ Latvia [2006] Eur. Ct. H.R., App. No. 58278/00, the European Court of Human Rights held that although a state will be afforded a margin of appreciation in implementing electoral laws, such laws must not depart from accepted principles which give effect to the will of the people.

These legal principles are applied by the courts in the adjudication of electoral complaints in order to protect the will of the people. The danger, however, is that regardless of collusion in electoral laws and institutions in a country or jurisdiction, the legal principles for adjudicating electoral complaints assume that the outcomes of elections are pure and uncorrupted. They should only be invalidated in exceptional circumstances.

In many countries electoral laws indicate that the complainant must prove that these irregularities changed the outcome of the election in a substantial manner. This is in instances where the validity of the election is challenged on the basis of irregularities. Examples of these include the Elections Act No. 24 2011, s.83 of Kenya; the Law on the Elections of Member of Parliament 2002, art.100 (2) of Macedonia; and the Presidential and Vice-President Election Act No.31 1952, art.18(b) of India. This is because elections are meant to give a voice to the will of the people and to provide governments with the authority to exercise power. Therefore, technical irregularities during elections should not affect the declared results unless they distort the will of the people by changing the election outcome. Courts in many jurisdictions have held that election outcomes should only be overturned in extraordinary circumstances, where evidence of illegality, dishonesty, unfairness, malfeasance or other misconduct is clear; and most importantly where such improper behaviour has distorted the will of the people. Some of the authoritative cases are:

- in England: Morgan \& Others v Simpsons [1974] 3 ALL E.R 722, [1975] QB 151)-;

- in Nigeria: Alhaji Mohamed D. Yusuf v Chief Olusegun A. Obasanjo \& Ors SC.122/ 2003, 2003(10) LEDLR 1, [2003];

- and in United State of America: Andrews v Blackman, 59 So.769 (La.1912).

This globally accepted legal concept, which is intended to protect the will of the people, forms the basis for annulling elections under s.59(6)(a). It is, therefore, widely conceived that candidates, parties and their supporters who lose elections in which minor irregularities occurred, should accept the outcomes, rather than routinely claim that the governments they produce are illegitimate. In this 
regard, the Supreme Court in Uganda did not stray from international principles for adjudicating electoral complaints. There are, however, several reasons for criticising the Supreme Court decisions, as discussed below.

\section{WEAKNESSES IN THE LAW}

Despite the Supreme Court's findings of widespread violations of electoral laws, it held that these violations were not personally committed by President Museveni or with his knowledge or approval by his agent. The overall effect of such electoral offences was that they distorted the will of the people. This study asserts that the legislative intent of s.59(6)(c) is to prevent presidential candidates from both committing electoral offences similar to those witnessed during the 1980 elections, and benefitting from them. Given the Court's findings, it is reasonable to conclude that President Museveni acquired advantages in the elections as the result of electoral offences which also disadvantaged the electorate. The law should allow for elections to be annulled in instances where a candidate gains advantages over competitors, or disadvantages the electorate as a result of widespread violations of electoral laws. This should be regardless of whether the violations were personally committed by the candidate declared as president or with their knowledge or approval by their agent.

Where electoral gains are a result of offences such as intimidation or bribing voters, the will of the people is distorted and this influences the outcome of the elections. The will of the people cannot be said to be protected where there is evidence of widespread and distorting electoral violations. The fact that these irregularities are ignored is largely because the violations were not committed by the victorious candidate, or by agents with the candidate's knowledge or approval. Perfect compliance with electoral laws in every instance is unlikely, and the Court should avoid nullifying an election for minor violations or technical requirements. However, the law should indicate whether the violated electoral laws are mandatory or directory. Mandatory provisions would include those that prohibit voter disenfranchisements, such as bribing voters and voter intimidation. Widespread violations of such provisions distort the will of the people and should form the basis of annulling an election regardless of whether or not they are committed by the victorious candidate, or by their agent with their knowledge or approval. Directory provisions would be those that require candidates to conduct themselves in a respectful manner towards each other, such as those which prohibit defamatory remarks among candidates.

The Supreme Court has acknowledged the presidency's domination over all institutions of government and that President Museveni has gained an unfair advantage over his competitors through using state resources in the electoral 
process (PEP No.1 2016, para. 37). It is, therefore, impossible to imagine how President Museveni, who has the state resources and machinery at his disposal, could fail to hide evidence of electoral offences that he has committed, or those committed by his agent with his knowledge or approval, in order for the Court to annul the elections under s.59(6)(c). Moreover, in civil proceedings such as electoral challenges, the burden of proof should lie with the petitioner to prove to the Court the allegations made against the respondent on the standard of 'the balance of probabilities' (F.H. v McDougall (2008) S.C.J. No. 54). However, the Supreme Court's decisions (PEPS No.1 2001, No.1 2006 and No.1 2016), indicate that the petitioner must prove, 'to the satisfaction of the Court', the allegations made against the respondent on a higher threshold, that is 'beyond reasonable doubt', which is the standard of proof required to validate a criminal conviction (Grechieng, Niclisch \& Thoeni 2010, pp. 847-862). This imposes an almost impossible task for the challenger of the election's outcome. For these reasons, s.59(6)(c) is deficient in preserving the will of the people and in facilitating fair competition for the presidency.

\section{INTERPRETING S.59 (6)(A) OF THE PRESIDENTIAL ELECTION ACT 2010}

When interpreting the phrase 'affected the results of the election in a substantial manner' under s.59(6)(a), the Supreme Court in PEP No.1 2001 was guided by two authorities, namely, the cases of Mbowe v Eliufoo (1967) EA 240 and Re Kensington North Parliamentary Election [1960] 1 W.L.R 762, [1960] 2 ALL E.R 150. In the former case, Georges CJ defined the phrase 'affected the result 'as follows:

In my view, the phrase 'affected the result' the word 'result' means not only the result in the sense that a certain candidate won and the other lost. The result may be said to be affected after making an adjustment, the effect of proved irregularities the contest seems much clear closer than it appears to be when first determined. But when the winning majority is so large that even a substantial reduction still leaves the successful candidate a wide margin, then it cannot be affected by any noncompliance of the rules (1960, para. 242).

In the latter case, Justice Boyce (1967, para. 115) reasoned that:

Out of the total voting electorate of persons who recorded their votes, 3 or possibly 4 were shown by the evidence to have voted without having a mark placed against their names in the register and each of them voted only once. Even if one was to assume in favour of the 
Petitioner that some proportion of the remainder 111 persons, who we have not seen were in somewhat similar case, there does not seem to be a thread of evidence that there is any substantial noncompliance with the provision requiring a mark to be placed against the voters names in the register; and when the only evidence before the court is that 3 or possibly 4 people who are affected in that they recorded their votes without a mark placed against their names, each voted only once, one cannot possibly come to the conclusion that although there was a breach of statutory rules, the breach could have had any effect on the result of the election. Even if all the 117 persons were similarly affected, it could not possibly have affected the result of the election; therefore, although there was a breach in regard to the matter set out in para 3(1) of the petition, I should be prepared to say that there was a substantial compliance with the law in this respect governing elections and that omission to place a mark against the names did not affect the result.

In order to determine that the electoral malpractices did not affect the outcome of the elections in a substantial manner, the courts in Mbowe (1967) and in Re Kensington (1960), took a similar approach. They quantified the number of votes which the petitioners alleged they were deprived of as the result of the electoral malpractices, and deducted that number from the total votes cast in favour of the respondents. This was in order to determine if 'but for' the malpractices, the petitioners would have won the election. The courts could not invalidate the election where the majority margin between the respondent and the petitioner was so wide that even allowing for the votes deprived of the petitioner as a result of the malpractices, the respondents would still have won the election. In Mbowe (1967), there were 30889 voters on the register, of which 6393 voted for the petitioner and the respondent was declared the winner with 20213 votes. The majority margin between the respondent and the petitioner was 13 820; 4238 people did not vote. Even though the petitioner satisfied the Court that the respondent had intimidated his voters, it could not invalidate the election because the majority margin between the respondent and the petitioner was so wide. Assuming that 4238 people did not vote because of intimidation and would all have cast their votes for the petitioner, the petitioner would still not have won the election.

There is, however, a problem when it is not possible for the court to determine the number of voters that may have been affected by the electoral malpractices. For example, in the 2001 presidential election, the Supreme Court found evidence of widespread voter bribing and intimidation (PEP No.1 2001, para.67). It was not possible for the Court to quantify how many voters were bribed to vote for President Museveni or how many people did not vote because they were 
intimidated by the President's supporters. The facts, however, tell a different story. According to the Uganda Electoral Commission's Report (2001), President Museveni acquired 5123609 votes and Kizza Besigye polled 2055 795. The other presidential candidates polled as follows: Awori Aggrey, 103 915; Bwengye Francis, 22 751; Karuhanga Chappa, 10 080; and Kibirige Mayanja Muhammad, 7379 . The total number of votes cast in the election was 7389 691, and there were 10775836 persons on the electoral register.

The majority margin between the President and the petitioner was 3067 565. According to evidence submitted to the Court by the Uganda Electoral Commission (PEP No.1 2001, para. 87), the total number of invalid votes cast was 186453. Therefore, 3386145 people did not vote and could have been prevented from doing so by the intimidation meted out by President Museveni's supporters. Even though it was not possible to ascertain their reasons for not voting, the number of eligible voters that did not vote (3386145) was more than the majority margin between President Museveni and the petitioner (3067565) without considering the invalid votes cast (186453). It is also not known how many people were bribed to vote for the President. Do these facts suggest that the Supreme Court got it wrong? Although it is not possible to ascertain the reasons why 3386145 people did not vote, on analysis the facts damage the credibility of the elections and the legitimacy of Museveni's presidency. It should be noted that in a country with an unenviable record of electoral malpractices, the Supreme Court had the option of ordering a new election under s.59(5) when there was any doubt about electoral legitimacy.

\section{ELECTION RESULTS: A QUESTION OF QUALITY NOT QUANTITY}

The legitimacy of a democratic government is established in large measure by credible elections. Credible elections occur in an electoral environment in which the citizenry can participate without fear or obstruction; political parties, candidates, and the media can operate freely; and independent state and democratic institutions function fairly and expeditiously. Also, electoral laws must be fair, they should be adhered to, and they should be capable of translating votes into the free will of the people in order to preserve the credibility of elections.

It is therefore important that the law should seek to protect all aspects of the electoral process in order to preserve the credibility or quality of elections. In some jurisdictions, electoral laws seek to achieve this aim. Examples of these include the Election Act 173 1988, s.56(a) of South Africa which allows the Electoral Commission or the Electoral Court to declare elections invalid where a serious irregularity has occurred concerning any aspect of an election. Also the Electoral Act 2010, s.138 (b) of Nigeria provides that elections may be annulled by reason of 
corrupt practices or noncompliance with the provisions of the same Act. Courts have also strived to protect the quality of elections. In the case of Valance $v$ Rosier 675 So. 2d 11389 La Ct App 1996, the Supreme Court of Louisiana (1996, para. 32) held that:

If the court finds that the proven frauds and irregularities were of such serious nature as to deprive the voters of the free expression of their will, or as to make it impossible to determine the outcome of the election, it will decree the nullity of the entire election even though the contestant cannot prove that he would have been elected but for such fraud or irregularities.

This case stands for the proposition that where widespread violations of electoral laws occur, they affect the quality of the elections because they distort the will of people and therefore the elections should be annulled.

Another example of where the court invalidated an election because it was conducted so badly that the credibility of the election could not be assured, is in the Hackney Case, Gill v Reed and Holms[1874] 2 O M \& H 77 E.L.R 263. In this case, only 2 of the 19 polling stations were closed; as a result, 5000 voters could not vote. The court did not engage in the impossible exercise of determining which candidate would have benefited from 5000 votes had they been cast. It annulled the election on the basis that it was badly conducted and in noncompliance with electoral laws.

In this context, the term 'election result' is conceived of as a question of quality informing an election's outcome. It is seen as the entire electoral process not limited to only the votes tallied, because the outcome of the election cannot be guaranteed where the processes that deliver it are corrupted

Uganda's only post-independence attempt at conducting elections in 1980 was marred by electoral illegalities (Tamale 1980). Also, history indicates that unelected leaders have held political power at all costs. These factors, including the need to reverse the country's history of political and constitutional instability, (as expressed in the Preamble and art.1(4) of the Constitution) motivated the country's desire to hold free and fair elections in order to be ruled by consent. During the public debates on the Constitution, Ugandans demanded that 'electoral laws should be built into the new constitution in order for elections to be the mechanism for the smooth transfer of power from one administration to another' (CCR 1992, p. 89).

In PEP No.1 2006, the Supreme Court found instances of ballot paper stuffing in at least 22 out of the 69 districts. Over 2000 ballot papers were stuffed at one polling station and more than 600 people voted at a sham polling station (2006, 
para. 54). It also found evidence of falsification of results by the Uganda Electoral Commission, and voter intimidation and voter bribes by persons associated with the president (2006, para.124). In PEP No.1 2016 the court criticised the Uganda Electoral Commission for late delivery of voting materials, which led to a substantial number of voters being unable to vote. The commission was also accused of failing to provide a credible explanation as to why the results of the election were delayed or missing in 1787 polling stations (2016, paras. 97 and 123). It also noted that in some cases, the petitioner's agents were denied information to which they were entitled. Among other acts of electoral lawlessness the police and other security agencies interfered with the petitioner's electioneering activities (2016, paras 145-149). These widespread electoral malpractices violated core constitutional values in that they undermined the principles on which the new democratic dispensation in Uganda was founded. In doing so they affected the quality of elections as envisioned by the citizenry of Uganda and as provided for in the Constitution.

The conclusion was that the election was not only noncompliant with domestic electoral laws but also disregarded core constitutional values. Thus the quality and result of the election were affected in a substantial manner, in terms of s.59(6)(a). The result of the elections is interpreted to mean the number of votes cast but not the quality of the electoral process, as has been preferred by the Supreme Court, fails to protect the quality of elections. It also defeats fair political contestation and it is inadequate in protecting the will of the people.

\section{CONCLUSION}

An analysis of the post-1995 constitutional and domestic legal framework under which the president of Uganda is elected reveals that it is deficient in facilitating fair political contestation and in promoting democracy. This is mainly because presidential electoral laws make it almost impossible to challenge the outcome of the election, particularly when the present incumbent is declared victorious. Also, electoral laws have been interpreted without the judicial activism necessary to address issues of electoral lawlessness and the challenges to elections pertaining to Uganda. Moreover, the abolishment of the presidential term limits without the popular consent of Ugandans has enshrined a president-for-life who commandeers the Constitution and all instruments of state power. Presidential elections in Uganda have failed to display the procedural fairness and substantive uncertainty that makes democratic elections normatively acceptable. As such, they are incapable of offering the prospects of transferring power. They may be perceived as an institutional facade of democracy aimed at concealing the harsh realities of an entrenched regime. They do not offer a choice, are not a 
symbol of popularity or legitimacy, and they have failed to translate votes into a democratic choice. Presidential elections in Uganda are a periodical ritual that affirms President Museveni's grip on power.

\section{REFERENCES}

Afedura, \& Atuhaire LA 2003, 'Court Blocks anti-3rd Term Review Report', Monitor 9 December, p.3.

African Charter on Democracy, Elections and Governance 2007, Assembly/AU/ Dec.147 (VIII), adopted on 30 January 2007.

Alhaji Mohamed D. Yusuf v Chief Olusegun A. Obasanjo \& 56 Ors SC.122/2003, 2003(10) LEDLR 1, [2003].

Amama Mbabazi v Museveni \&Ors. [2016] 1 UGSC 3.

American Convention on Human Rights 1969, OAS Treaty Series No. 36; 1144 UNTS 123; 9 ILM 99 (1969) adopted 22 November 1969.

Asiimwe, G \& Muhozi, 2005, The State of Constitutional Development in Uganda for the Year 2005, East African Centre for Constitutional Development.

Barkan, J 2005, 'Uganda: An African Success Past Its Prime?' , Wilson International Centre for Scholars, Challenges and Change in Uganda Conference, Washington, 2 June.

Angola 2010, Constitution of Republic of Angola 2010, art. 4 (1)

Benin 1990, Constitution of the Republic of Benin 1990, art. 3-6

Col. Dr. Besigy eKiiza v Museveni Yoweri Kaguta and the Electoral Commission [2001] 1 UGSC3.

European Convention for the Protection of Human Rights and Fundamental Freedoms 1950 adopted 4 November 1950.

European Union 2012, Compendium of International Standards for Elections: Status of Ratification, European Commission, Kampala.

European Union 2016, Uganda's 2016 Presidential, Parliamentary and Local Council Elections, European Union, Brussels.

F.H. $v$ McDougall 2008, S.C.J. No. 54.

Grechieng, K, Niclisch, A \& Thoeni, C 2010, 'Punishment Despite Reasonable

Doubt - A Public Goods Experiment with Sanctions under Uncertainty', Journal of Empirical Legal Studies, vol.7, no. 4, pp. 847- 862.

India 2012, The Presidential and Vice-presidential Elections Act, 1952 (Act No. 31 of 1952, art. 18) and Rules as on the 15th May.

International Covenant on Civil and Political Rights 1966, adopted 16 December 1966 UN G.A Res. 2200A (XX1).

Kasozi, A 1994, The Social Origins of Violence in Uganda 1964-1985, McGill Queens University Press, Montreal. 
Re Kensington North Parliamentary Election [1960] 1 W.L.R 762, [1960] 2 ALL E.R 150. Kenya 2011, Election Act No.242011, s.83.

Kiwanuka, S 2003, 'Strong Presidency Will Move Country Forward', Monitor 6 November, p.4.

Luis Felipe Bravo Mena v Mexico [1993] (10/7/93), Case 10.956 IACHR.

Macedonia Law on the Elections of Members of Parliament 2002. Art.100 (2)

Mbowe v Eliufoo (1967) EA 240

Mudola, D 1988, ‘Political Transitions since Idi Amin: A Study in Political Pathology' in HB Hansen \& M Twaddle (eds), Uganda Now: Between Decay and Development, Oxford University Press, Oxford.

Mukasa, M 1980, 'Mayhem at DP Rally' Weekly Topic 18 July, p.2

Museveni, Y 1997, Sowing the Mustard Seed: The Struggle for Freedom and Democracy In Uganda, Macmillan Education, London.

Ngozi, B 2003, The State of Constitutionalism in Uganda in 2003, East African Centre for Constitutional Development, Kampala.

Nigeria, 2010, Nigeria Electoral Act 2010, s.138(b).

Posner, D and Young, D 2010, 'The Institutionalisation of Political Power in Africa', Journal of Democracy, vol. 18, no. 2, pp. 127-140.

Rtd. Col Kizza Besigye v the Electoral Commission and Yoweri Kaguta Museveni [2006] UGSC 2.

South Africa, 1998, Electoral Act 73, s.56(a)

Tamale, J 1980, 'Violence Mars Political Campaigns', The Citizen 25 August, p.4. Uganda 1967, Constitution Government Publishers, Kampala.

1995, Constitution. Ministry of Constitutional Affairs, Kampala.

Uganda Constitutional Commission 1993, The Report of the Uganda Constitutional Commission, Uganda Constitutional Commission, Kampala.

Uganda Constitutional Review Commission 2003, The Report of the Commission of Inquiry (Constitutional Review): Findings and Recommendations, Ministry of Justice and Constitutional Affairs, Kampala.

Uganda 2005, Constitutional Amendment Act.

2010 Electoral Commission Act.

2010 Political Parties and Organisations Act.

2010 Presidential Elections Act.

Uganda Electoral Commission 2001, Report of the Presidential Elections, Uganda Electoral Commission, Kampala.

Uganda Electoral Commission 2006, Report of the Presidential Elections, Uganda Electoral Commission, Kampala.

Uganda Electoral Commission 2007, A Brief History of Elections in Uganda, Uganda Electoral Commission, Kampala. 
Uganda Electoral Commission 2016, Presidential Election Report, Uganda Electoral Commission, Kampala.

United States Agency for International Development (USAID) 2005, Democracy and Governance Assessment: Republic of Uganda, Washington.

Universal Declaration of Human Right 1948, GA. Res. 217A (III), U.N. Doc A/810, adopted on 10 December 1948.

Valance v Rosier 675 So. 2d 11389 La Ct App 1996.

Zdanoka v Latvia, Eur. Ct. H.R., App. No. 58278/00, Judgment of 16 March 2006. 